\title{
Review Komposit Pati-Kitosan: Perannya dalam Berbagai Sistem Penghantaran Obat
}

\section{Putri Nabila Zulvianti ${ }^{1}$, Pramulani Mulya Lestari², Nining Nining ${ }^{*}, 2$}

1Program Studi Sarjana Farmasi, Fakultas Farmasi dan Sains, Universitas Muhammadiyah Prof. DR. HAMKA, DKI Jakarta, Indonesia

2Unit Bidang IImu Teknologi Farmasi, Fakultas Farmasi dan Sains, Universitas Muhammadiyah Prof.

DR. HAMKA, DKI Jakarta, Indonesia

*Email: nining@uhamka.ac.id

(Submit 6/11/2021, Revisi 24/11/2021, Diterima 14/12/2021, Terbit 12/2/2022)

\section{Abstrak}

Pati adalah polisakarida yang berasal dari alam yang banyak terdapat secara luas dalam biji, buah, akar, dan batang. Pati sering digunakan sebagai zat tambahan dalam sediaan farmasi karena memiliki sifat polimer hidrofilik, tidak beracun, biodegradabel, inert, biokompatibilitas, mudah ditemukan dan harganya relatif murah. Optimalisasi fungsi pada penggunaannya di bidang farmasi seringkali digabungkan dengan kitosan sebagai komposit. Penggabungan tersebut dapat meningkatkan kelarutan, mengurangi toksisitas dalam tubuh, meningkatkan aktivitas farmakologi, meningkatkan stabilitas, meningkatkan biodegradabilitas dan memberikan sifat unggul pada sediaan. Penulisan review artikel ini bertujuan untuk mengumpulkan informasi tentang penggunaan komposit pati-kitosan sebagai eksipien dalam berbagai sistem penghantaran obat. Penulisan artikel berdasarkan review pustaka yang ditelusur pada database Google, Google Scholar, Science Direct, Pubmed dan MDPI. Sumber pustaka yang digunakan pada rentang tahun 2011-2021; kriteria inklusi yaitu komposit pati-kitosan yang memiliki peran dalam sistem penghantaran obat; kriteria eksklusi yaitu pati dan kitosan yang tidak relevan. Berdasarkan review pustaka yang dilakukan, didapatkan hasil bahwa pati dan kitosan membentuk komposit yang dapat digunakan dalam sistem penghantaran obat seperti film, nanopartikel, tablet dan gel. Penggunaan komposit pati-kitosan sebagai material baru memberikan peningkatan manfaat dan optimalisasi fungsi dalam berbagai bentuk sediaan farmasi dibandingkan dengan penggunaan tunggal.

Kata kunci: Eksipien, kitosan, komposit polimer, pati, sistem penghantaran obat

\section{Pendahuluan}

Eksipien farmasi merupakan suatu zat tambahan selain zat aktif yang ditambahkan ke dalam formulasi atau proses pembuatan pada sediaan farmasi ${ }^{1}$. Eksipien yang digunakan harus memiliki beberapa sifat diantaranya tidak toksik, stabil secara fisika maupun kimia, inert secara farmakologi dan harganya relatif murah². Eksipien digunakan untuk tujuan dan fungsi tertentu tergantung jenis sediaan yang dibuat, penambahan eksipien dengan zat aktif dapat memberikan perlindungan pada zat aktif, meningkatkan stabilitas, meningkatkan keamanan dan efektifitas dari sediaan itu sendiri ${ }^{1}$ 
Eksipien yang sering digunakan dalam sediaan farmasi yang berasal dari alam salah satunya adalah pati.

Pati adalah polisakarida yang berasal dari alam yang banyak terdapat secara luas dalam biji, buah, akar, dan batang. Pati terdiri dari dua jenis molekul yaitu amilosa dan amilopektin dengan struktur kimia yang tersusun seperti Gambar 1. Amilosa berbentuk heliks dengan molekulnya terikat oleh $\alpha-(1,4)$-D-glukosa, dengan berat molekul rataratanya adalah $105 \mathrm{Da}$. Sebaliknya amilopektin adalah kelompok polimer bercabang yang tiap unitnya dihubungkan secara linier oleh ikatan $\alpha-(1,4)$ pada rantai lurusnya, serta ikatan $\alpha-(1,6)$ pada titik percabangan ${ }^{3}$. Pati termasuk kedalam polimer alam, karena pati dihasilkan dari pemanfaatan karbon dioksida dan air melalui proses fotosintesis, serta dapat terdegradasi dengan sempurna ${ }^{4}$.

(a)

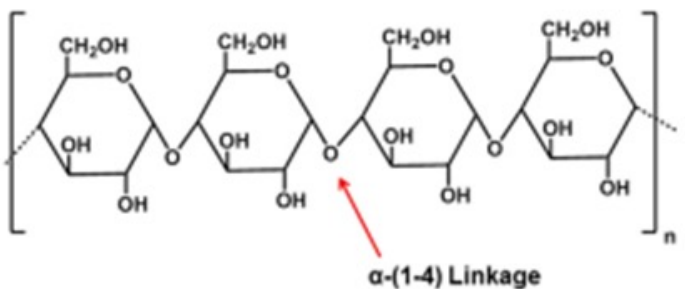

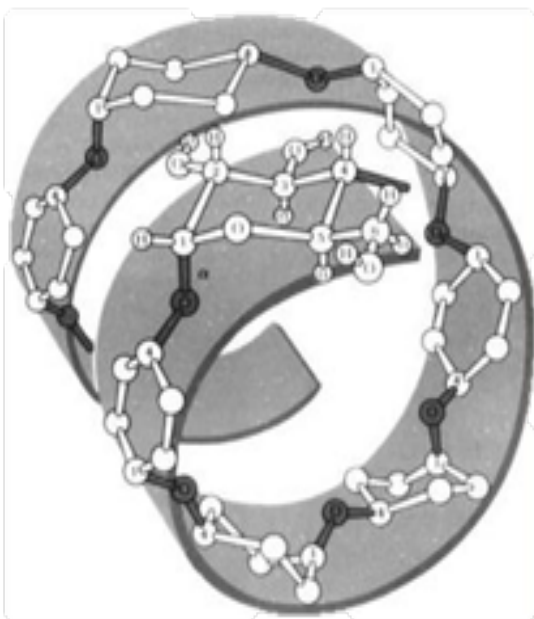

(c) (b)

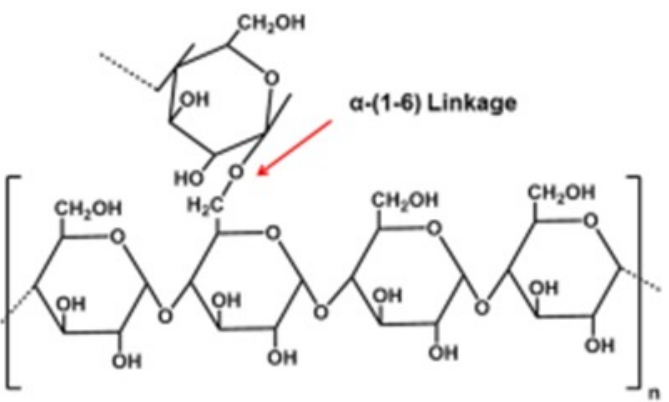

Gambar 1 Struktur kimia (a) amilosa (b) amilopektin dan (c) heliks amilosa

Pati mulai banyak digunakan sebagai salah satu zat tambahan dalam sediaan farmasi karena pati memiliki sifat polimer hidrofilik yang dapat dengan mudah diubah menjadi berbagai bentuk karena tidak beracun, bersifat biodegradabel, inert, biokompatibilitas, mudah ditemukan dan harganya relatif murah ${ }^{3,5}$. Maka dari itu pati sering sekali digunakan dalam sediaan farmasi karena pati dapat berfungsi sebagai pembawa obat yang dapat meningkatkan kelarutan obat, meningkatkan biokompatibilitas, mengurangi efek samping dari molekul obat, dan stabilitas penyimpanannya ${ }^{6}$. Namun sering kali pati yang digunakan dalam sediaan farmasi masih memiliki beberapa kekurangan seperti sukar larut dalam air dingin, sifat alir yang buruk, kompaktibilitas yang buruk ${ }^{2}$, sifat mekanik dan produk akhir yang buruk ${ }^{7,8}$. Sehingga perlu penambahan dari material lain yang mampu membantu fungsi dari pati agar lebih fungsional atau efektif. Pati sering digabungkan dengan polimer lain sebagai pengisi atau penguat; salah satu polimer yang sering di gabungkan dengan pati yaitu kitosan.

Kitosan merupakan karbohidrat alami yang mudah di dapatkan dan termasuk kedalam polimer molekul tinggi yang dapat diperoleh melalui deasetilasi kitin seperti yang terlihat pada Gambar $2^{9}$. 
Kitosan merupakan polisakarida rantai linier yang terdiri dari $\mathrm{N}$-acetyl-2-amino-2-deoxy$d$-glucopyranose (unit asetat) dan 2-amino 2-deoxy-d-glucopyranose (unit deasetilasi), dimana unit berulangnya dihubungkan oleh ikatan $\beta-(1,4)$-glikosidik ${ }^{10}$. Sifat fisikokimia pada kitosan memiliki banyak potensi diantaranya yaitu mudah membentuk gel, film, partikel, serat nano dan scaffolding. Sedangkan untuk sifat biologisnya kitosan bersifat tidak beracun, biokompatibel, biodegradabel, sitotoksisitas rendah, memiliki aktivitas hemostatik, dan kemampuannya dalam mengikat logam 3,11,8,12.

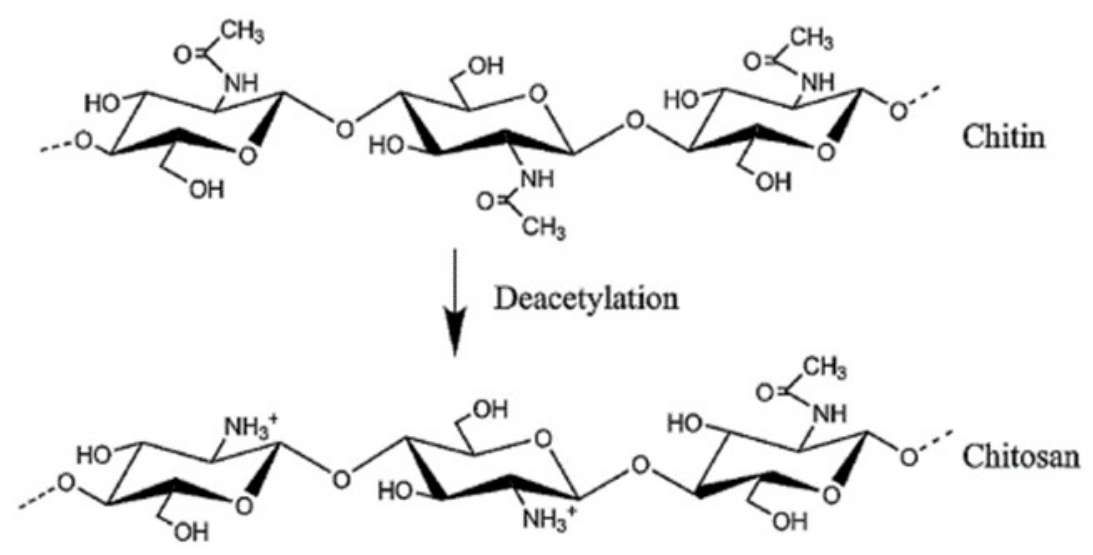

Gambar 2 Struktur kimia kitosan

Kitosan sering kali digunakan sebagai pembawa obat karena dapat memberikan peningkatan manfaat seperti pelepasan obat terkontrol dan lambat, meningkatkan stabilitas dan kelarutan obat, dan meningkatkan khasiat ${ }^{7}$. Selain itu, kitosan juga memiliki imunogenisitas yang rendah dan kapasitas adsorpsi yang tinggi, sehingga kitosan sering direkomendasikan sebagai salah satu komponen terbaik yang digunakan dalam sistem penghantaraan obat ${ }^{6}$

Kitosan dan pati sama-sama memiliki kekurangan dan kelebihan berdasarkan sifat fisika maupun kimianya. Kitosan memiliki beberapa kekurangan diantaranya kelarutannya rendah dalam air, dan sifat mekanik buruk yang mengakibatkan kerapuhan pada suhu kamar ${ }^{3}$. Beberapa upaya yang dapat dilakukan untuk mengembangkan bahan fungsional kitosan diantaranya dengan pencampuran kitosan pada polimer alam, polimer sintetik, atau mineral alam yang dapat digunakan untuk meningkatkan sifat mekanik dan bioavailabilitasnya ${ }^{3}$. Pencampuran material tersebut merupakan pendekatan alternatif untuk menggabungkan serangkaian karakteristik fisiko-mekanis yang diinginkan dalam material baru ${ }^{9}$.

Penggunaan pati maupun kitosan sebagai eksipien farmasi telah banyak digunakan tetapi untuk memaksimalkan hasil atau fungsional dari kedua material tersebut pati dan kitosan sering digabungkan menjadi satu material baru yang dimana kekurangan dan kelebihan dari kedua material dapat di tutupi satu sama lainnya. Pencampuran pati dan kitosan merupakan salah satu cara untuk meningkatkan sifat mekanik, penghalangan uap air, sifat antimikroba, meningkatkan biodegradabilitas pada film kitosan ${ }^{13}$ serta dapat memberikan sifat unggul pada sediaan ${ }^{14}$. Penggabungan dari penambahan material tersebut biasa disebut juga sebagai komposit ${ }^{15}$. 
Komposit merupakan suatu sistem campuran atau gabungan dari dua jenis material atau lebih ${ }^{16}$. Pada dasarnya, penggabungan dilakukan pada dua material yang sifatnya berbeda satu sama lain seperti bentuk, komposisi, sifat fisika dan kimianya ${ }^{15}$. Tujuan pembentukan komposit adalah untuk menghasilkan material dengan sifat baru yang berbeda dengan sifat material penyusunnya, serta saling menutupi kelemahan dari kedua jenis material tersebut ${ }^{17}$. Selain itu, material baru diharapkan memiliki sifat mekanik, fisika, dan kimia yang lebih baik dibandingkan material penyusunnya ${ }^{18}$. Secara fungsi, komposit tersusun atas dua komponen. Komponen pertama berupa matriks yang berfungsi sebagai pengikat dan melindungi pengisi dari kerusakan eksternal; komponen kedua berupa pengisi yang berfungsi sebagai penguat matriks. Pembentukan komposit terjadi karena adanya ikatan permukaan antara matriks dan pengisi akibat gaya adhesi dan kohesi ${ }^{15}$. Ikatan pada komposit terbentuk dari interaksi kitosan yang bermuatan positif dan polimer lain yang bermuatan negatif ${ }^{44}$.

Tujuan dari artikel review ini adalah untuk mengumpulkan informasi tentang komposit pati-kitosan sebagai eksipien dalam sistem penghantaran obat. Sebagai salah satu contoh, peneliti menemukan bahwa komposit pati-kitosan dapat digunakan pada film dan dapat meningkatkan ketahanan air, laju transmisi uap air ${ }^{3}$, fleksibilitas yang lebih tinggi dan peningkatan elongas $i^{9}$. Maka dari tinjauan ini diharapkan dapat memberikan informasi tentang pemanfaatan komposit pati-kitosan pada berbagai sistem penghantaran obat lainnya.

\section{Metode}

Pencarian melalui database Google, Google Scholar, Pubmed, Science Direct, dan MDPI. Dengan kata kunci "komposit pati", "komposit", "komposit pati sebagai eksipien farmasi", "starch", "composite starch for drug delivery system", "composite starchchitosan" dan "composite starch with chitosan for drug delivery system".

Ekslusi:

Studi Non-Pati $(\mathrm{n}=20)$

Studi Pati tidak relevan $(\mathrm{n}=30)$

Skrining awal $(\mathrm{n}=93)$

Artikel yang direview $(n=43)$

Gambar 3 Diagram alir penyusunan literatur 
Metodologi penulisan artikel review ini dilakukan dengan penelusuran pustaka yang bersumber dari data primer yang di dapat dari jurnal ilmiah yang diterbitkan secara nasional dan internasioal. Pustaka yang digunakan kemudian dilakukan skrining jurnal dengan kriteria inklusi pada batasan publikasi selama 10 tahun terakhir dengan rentang tahun 2011-2021. Kriteria inkulsi yaitu komposit pati kitosan yang memiliki peran dalam sistem penghantaran obat; kriteria eksklusi yaitu pati dan kitosan yang tidak relevan. Pencarian jurnal dilakukan secara online yang diakses dari beberapa situs berupa Google, Google Scholar, Pubmed, Science Direct, dan MDPI. Pencarian yang dilakukan dengan menggunakan bahasa indonesia dan bahasa inggris dengan kata kunci "komposit pati", "komposit", "komposit pati sebagai eksipien farmasi", "starch", "composite starch for drug delivery system", "composite starch-chitosan", dan "composite starch with chitosan for drug delivery system".

\section{Hasil dan Pembahasan}

Pati merupakan polisakarida alam yang banyak digunakan dalam berbagai bidang seperti makanan, tekstil, kosmetik, plastik, perekat, dan obat-obatan. Pati lebih banyak digunakan dalam dunia farmasi karena relatif murah dan sifat fisik dari pati yang dapat digunakan dalam bentuk sediaan padat-oral. Umumnya pati digunakan sebagai pengikat, penghancur dan pengisi, namun penerapannya dibatasi karena sifat fungsional yang buruk dari pati itu sendiri. Oleh dari itu, banyak penelitian yang telah dilakukan untuk meningkatkan fungsional pati dalam sediaan farmasi sebagai sistem penghantaran obat. Pati memiliki sifat unik yang memungkinkan dalam meningkatkan stabilitas dan kelarutan obat, mengurangi efek samping dan toksisitas obat, serta memiliki biokompatibilitas yang sangat baik ${ }^{7}$. Hal tersebut menjadi dasar penggunaannya dalam sistem penghantaran obat.

Sistem penghantaran obat merupakan gambaran bagaimana suatu obat sampai ke tempat target aksinya dan memberikan efek farmakologi ${ }^{19}$. Sistem penghantaran obat secara tepat dapat mengontrol laju pelepasan atau menargetkan obat ke situs tubuh tertentu yang dimana tumbuhnya sel asing atau penyakit, serta mengurangi efek samping yang ditimbulkan dan mengakibatkan dampak yang sangat besar pada sistem kesehatan ${ }^{17}$. Teknologi penargetan dilakukan dengan sistem penghantaran obat menuju ke tempat target yang dipengaruhi dengan menggabungkan obat ke dalam partikel pembawa seperti polimer, misel, mikrosfer, nanopartikel, liposom dan lain-lainnya. Pembawa ini akan memodulasi karakteristik pelepasan dan penyerapan obatnya ${ }^{11,20,21,22,23}$. Dalam sistem penghantaran obat, material yang digunakan harus memiliki beberapa sifat diantaranya biodegradabel, biokompabilitas yang tinggi ${ }^{19}$, tidak beracun, non-imunogenik, dan menghindari pengenalan oleh mekanisme imun host ${ }^{21}$. Salah satu material yang digunakan sebagai bahan dasar dalam sistem penghantaran obat adalah polisakarida. Material ini bisa berasal dari polimer alam maupun polimer sintetik, baik yang digunakan sebagai polimer tunggal, polimer modifikasi maupun polimer kombinasi ${ }^{19}$.

Polimer alam memiliki beberapa fungsi jika digunakan dalam sistem penghantaran obat diantaranya dapat meningkatkan kelarutan, 
mengurangi toksisitas dalam tubuh, memiliki sifat bioavailabilitas, meningkatkan aktivitas farmakologi dan meningkatkan stabilitas ${ }^{20}$. Oleh karena itu, fungsi utama polimer adalah untuk membawa obat ke tempat kerjanya. Obat yang dibawa dalam polimer ini akan dilindungi dari interaksi pada molekul lain yang dapat menyebabkan perubahan aktif pada struktur kimianya sehingga menyebabkan kehilangan aksi farmasinya. Selain itu, pembawa polimer dapat menghindari interaksi obat dengan makromolekul seperti protein yang mampu menyerap bahan aktif sehingga mencegah kedatangannya di tempat aksi ${ }^{23}$.

Pati dan kitosan merupakan polimer yang biasa digabungkan dan disebut sebagai komposit. Komposit polimer terdiri atas kombinasi antara polimer dan material pengisi berupa material anorganik, sintetik atau alam. Komposit polimer pati-kitosan dapat meningkatkan kekuatan mekanik komposit yang tahan terhadap suhu tinggi serta mampu menurunkan laju pelepasan amilosa. Komposit polimer dapat meningkatkan sifat mekanik, sifat ketahanan panas, penghalang (barrier) gas dan api yang secara luas digunakan dalam jumlah yang besar di berbagai penerapannya ${ }^{18}$. Kombinasi ini menghasilkan material yang lebih tahan terhadap sinar ultraviolet dibandingkan dengan menggunakan material tunggal ${ }^{7,24}$.

Penggabungan antara pati dan kitosan menunjukkan adanya reaksi kimia yang terjadi. Pergeseran puncak dari $1567 \mathrm{~cm}^{-1}$ (film kitosan) menjadi $1574 \mathrm{~cm}^{-1}$ (film pati-kitosan) pada hasil FTIR (Gambar 4) menunjukkan adanya interaksi antara gugus hidroksil pati dengan gugus amino kitosan ${ }^{25,22,26}$ membentuk ikatan hidrogen. Interaksi kimia ini terjadi karena adanya perubahan karakteristik pada puncak spektrum setelah pencampuran antara kedua zat. Selain itu, hasil XRD memperlihatkan karakteristik semikristal dari film komposit ini ${ }^{26}$. Pola sinar-X pada film pati-kitosan menunjukkan refleksi kristal pati tipe-B yang bergeser ke derajat yang sedikit lebih tinggi pada sekitar

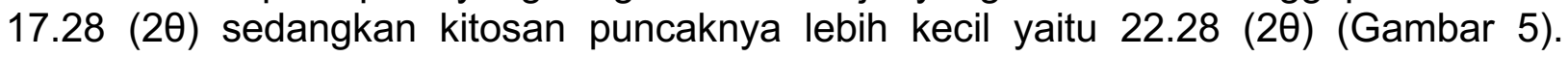
Pergeseran puncak difraksi pati dapat disebabkan oleh perubahan orientasi rantai yang disebabkan oleh pelapisan pada kitosan. Hal ini juga mungkin terjadi karena interaksi ikatan hidrogen antara kitosan dan molekul pati22. Dalam

penelitian lainnya, dikatakan penambahan pati dan kitosan secara signifikan dapat melemahkan kristalinitas film komposit dengan dihasilkan puncak yang melebar dan muncul dengan intensitas yang lebih besar pada $2 \theta=8 \sim 22^{\circ}$; hal ini menunjukan interaksi yang kuat antara pati dan kitosan yang dapat menghambat pembentukan puncak kristal dari film komposit pati-kitosan ${ }^{25}$.

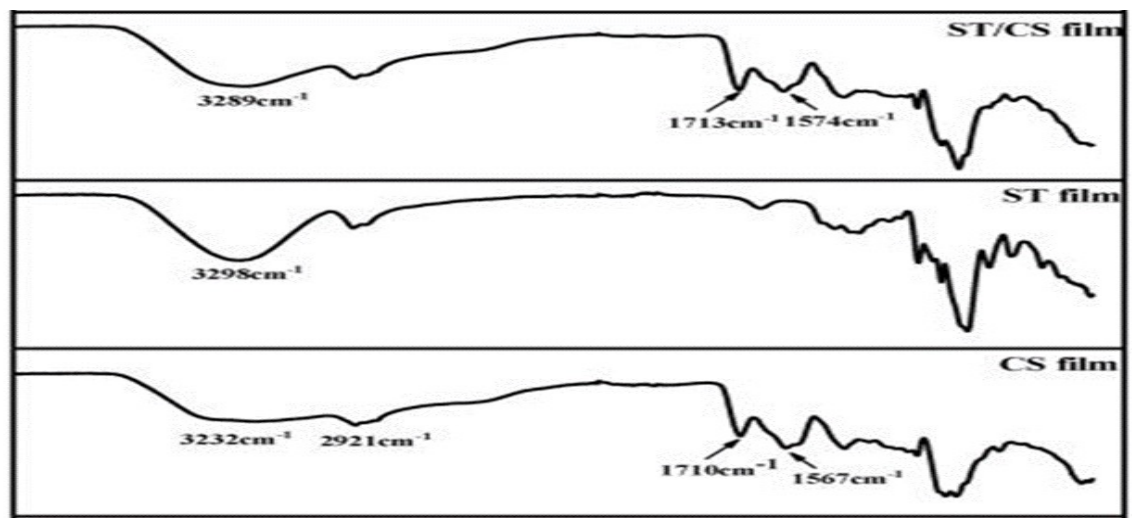


Gambar 4 Spektrum FTIR dari film pati (ST/ starch gelatinization solution film), film kitosan (CS/ chitosan solution film), film pati-kitosan (ST/CS film)

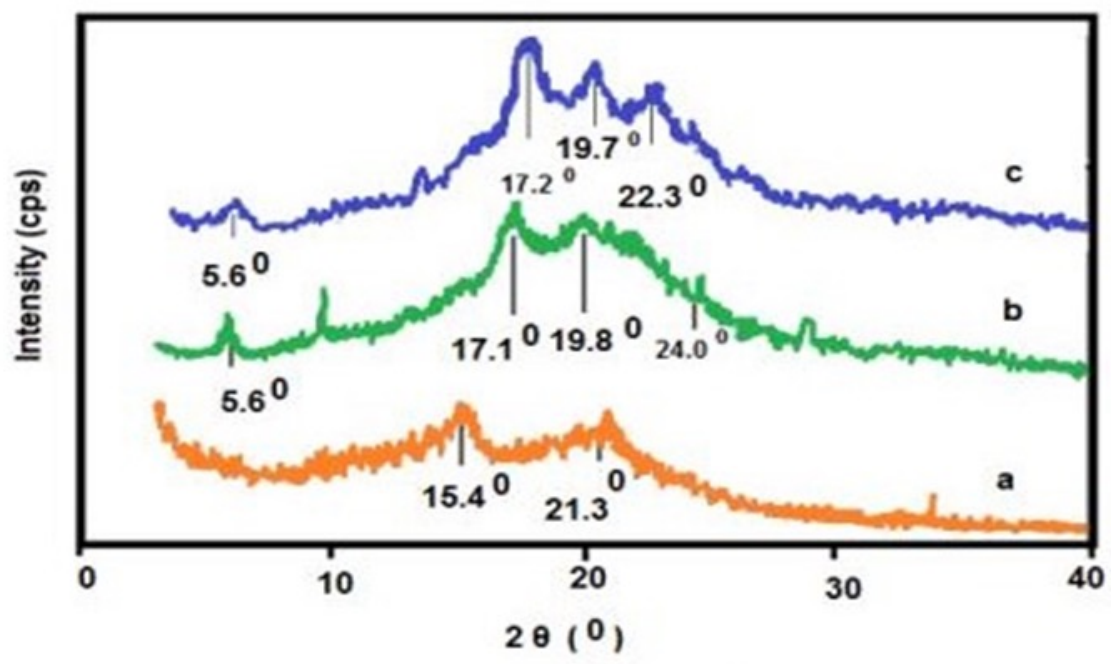

Gambar 5 Difraksi Sinar-X film kitosan bebas (a) film pati terplastisasi gliserol (b) film pati-kitosan

Dalam penggabungan pati dan kitosan, tidak hanya interaksi kimia saja yang terjadi. Teknik penggabungan juga berperan seperti penggunaan metode nanokomposit atau nanopatikel. Nanopartikel adalah partikel yang dibuat dalam ukuran nano dengan rentang 1-100 $\mathrm{nm}$, dan sering digunakan sebagai sistem dalam penghantaran obat ${ }^{27}$. Sedangkan nanokomposit adalah material yang terbuat dari polimer komposit yang dibentuk dalam ukuran nanometer dengan ukuran $\leq 100 \mathrm{~nm}^{18}$., Terdapat beberapa faktor yang paling penting dalam penghantaran obat berbasis nanopartikel yaitu ukuran partikel, sifat permukaan partikel, dan pelepasan obat ${ }^{27}$. Sistem pembawa nanopartikel dapat melindungi obat, mencegah kinetika pelepasan, meningkatkan penghantaran obat secara lokal ${ }^{5}$, menunjukkan pengurangan toksisitas dan dapat membatasi interaksi dengan sel sehat ${ }^{8}$. Penerapan nanopartikel berbahan dasar polimer telah banyak digunakan karena kemampuannya menembus ruang-ruang antar sel yang dapat ditembus oleh partikel koloidal, sehingga penerapannya bermanfaat dalam sistem penghantaran obat ${ }^{28}$.

Dalam sistem penghantaran obat, pati merupakan pembawa obat yang memiliki dampak penting dalam meningkatkan kelarutan suatu obat ${ }^{6}$. Sifat fisika kimia dari pati mampu berperan sebagai penghantar tetapi terdapat hal yang harus diperhatikan dalam membuat sediaan berbasis bahan alam tersebut yaitu kelarutan dan biovailabilitas dari senyawa bioaktif yang terkandung didalamnya ${ }^{20}$. Kitosan juga sering digunakan dalam sistem penghantaran obat karena sifat biodegradabel, toksisitas yang rendah dan bikompatibilitasnya ${ }^{11,23}$. Semakin berkembangnya ilmu semakin banyak juga penelitian yang menghasilkan produk-produk baru. Komposit pati-kitosan telah banyak digunakan dalam sistem penghantaran obat yang diringkas dalam dalam Tabel 1 . Sistem penghantaran yang dilaporkan meliputi bentuk film ${ }^{3,7,14,22,25,30,31}$, nanopartikel ${ }^{8,13,32}$, tablet $^{33,34,35,36}$, dan gel atau hidrogel $\left.\right|^{34,35,12,39}$. 


\section{Film}

Komposit pati-kitosan telah banyak digunakan sebagai film pada sistem penghantaran obat. Dalam penerapannya, hasil pengujian menunjukkan bahwa komposit meningkatkan secara signifikan sifat termostabilitas, mekanik dan morfologi akibat interaksi yang sinergis. Pengujian SEM dilakukan untuk melihat bentuk dan morfologi dari pati dan kitosan; hasilnya memperlihatkan bahwa film dari pati memiliki struktur yang halus dan kompak, sedangkan film dari kitosan menunjukan struktur berserat. Gabungan film antara pati-kitosan menunjukkan morfologi yang homogen dan halus tanpa adanya retakan pemisahan fasa, hal ini menunjukkan kompatibilitas yang tinggi antara pati dan kitosan ${ }^{25}$.

Sifat termostabilitas yang baik terjadi karena penggabungan kitosan dalam matriks selama proses plasticizing yang dapat meningkatkan interaksi molekul dan menghasilkan pembentukan ikatan- $\mathrm{H}$ antara makromolekul yang berbeda sehingga meningkatkan termostabillitas film ${ }^{30}$. Pada pengujian termogravimetri, dinyatakan bahwa penurunan berat menunjukkan tingkat biodegradasi campuran dan akan meningkat seiring dengan peningkatan kandungan kitosan ${ }^{22}$. Untuk pengujian studi permeabilitas uap air dan penyerapan air, hasil menunjukkan bahwa peningkatan kandungan kitosan dalam film pati menyebabkan difusivitas dan kelarutan molekul air dalam struktur mikro film berkurang secara intensif, serta ketahanan air film meningkat. Hal ini mengakibatkan pelepasan obat menjadi berkelanjutan. Ikatan silang dari kitosan memiliki hidrofilisitas yang lebih lemah dari pada pati sehingga sensitivitas air dari film menurun dengan penambahan kitosan, dimana kitosan berfungsi sebagai penghalang kelembaban dalam maktriks yang memiliki peran utama dalam ketahanan kelembapan film ${ }^{30,14}$.

Sedangkan untuk hasil tingkat transmisi uap air ditemukan bahwa interaksi antara kitosan dan molekul pati dapat menurunkan transmisi uap air dengan mencegah molekul air keluar melalui film. Amilosa dan amilopektin dapat mempengaruhi hasil ini karena film dengan kandungan amilopektin yang lebih tinggi memiliki transmisi uap air yang lebih tinggi ${ }^{3}$. Hasil transmisi uap air komposit film pati kitosan bernilai ideal untuk dapat dijadikan sebagai pembalut luka. Hal ini terjadi karena sifat transmisi uap air dari film komposit pati-kitosan dapat mempertahankan kelembapan luka yang sesuai dan mempercepat penyembuhan.

\begin{tabular}{|c|c|c|c|c|c|c|c|c|}
\hline $\begin{array}{l}\mathrm{N} \\
\mathrm{O}\end{array}$ & $\begin{array}{l}\text { Jenis } \\
\text { Pati }\end{array}$ & Jenis Kitosan & $\begin{array}{c}\text { Rasio } \\
\text { Pati: } \\
\text { Kitosan }\end{array}$ & $\begin{array}{c}\text { Peran } \\
\text { Eksipi } \\
\text { en }\end{array}$ & $\begin{array}{l}\text { Bent } \\
\text { uk } \\
\text { Sedi } \\
\text { aan }\end{array}$ & $\begin{array}{l}\text { Zat } \\
\text { Aktif }\end{array}$ & Tujuan & $\begin{array}{c}\operatorname{Re} \\
f\end{array}$ \\
\hline $\begin{array}{l}1 \\
.\end{array}$ & $\begin{array}{l}\text { Pati } \\
\text { jagung }\end{array}$ & $\begin{array}{l}\text { Kitosan } \\
\text { (derajat } \\
\text { deasetilasi } \\
\geq 95 \% \text { ) }\end{array}$ & $(1: 1)$ & $\begin{array}{l}\text { Polim } \\
\text { er } \\
\text { pemb } \\
\text { entuk } \\
\text { film }\end{array}$ & Film & $\begin{array}{l}\text { Zinc oxyde } \\
\text { nanoparticl } \\
\text { es ( } \mathrm{ZnO}- \\
\text { NPs) }\end{array}$ & $\begin{array}{l}\text { Untuk melihat pengaruh ZnO-NPs } \\
\text { dengan menggabungkan film kitosan- } \\
\text { pati pada sifat fisikokimia, aktivitas } \\
\text { antimikroba dan sitokompatibilitas }\end{array}$ & $\begin{array}{l}{[2} \\
5]\end{array}$ \\
\hline $\begin{array}{l}2 \\
.\end{array}$ & $\begin{array}{l}\text { Pati } \\
\text { jagung }\end{array}$ & $\begin{array}{l}\text { Kitosan } \\
\text { (derajat } \\
\text { deasetilasi } \\
89,2 \% \text { ) }\end{array}$ & $(1: 1)$ & $\begin{array}{c}\text { Matrik } \\
\text { s }\end{array}$ & Film & $\begin{array}{l}\text { Antofloxaci } \\
n\end{array}$ & $\begin{array}{l}\text { Untuk melihat efek kelayakan dalam } \\
\text { pembuatan mikrokapsul dan film } \\
\text { campuran kitosan-pati pada persiapan } \\
\text { sistem penghantaran obat baru untuk } \\
\text { aplikasi farmasi }\end{array}$ & $\begin{array}{l}3 \\
0]\end{array}$ \\
\hline
\end{tabular}




\begin{tabular}{|c|c|c|c|c|c|c|c|}
\hline 3. Pati & $\begin{array}{l}\text { Kitosan } \\
\text { (derajat } \\
\text { deasetilasi } \\
95 \% \text { ) }\end{array}$ & $(80: 20)$ & $\begin{array}{l}\text { Polim } \\
\text { er } \\
\text { pemb } \\
\text { awa } \\
\text { obat }\end{array}$ & Film & $\begin{array}{l}\text { MMT } \\
\text { (Cloisite } \\
\text { 30B) }\end{array}$ & $\begin{array}{l}\text { Untuk mencampurkan kedua } \\
\text { polimer dengan memvariasikan } \\
\text { proporsi nanoclay sehinggga } \\
\text { komposit dapat menjadi } \\
\text { pembawa obat yang lebih baik }\end{array}$ & $\begin{array}{l}{[2} \\
2]\end{array}$ \\
\hline $\begin{array}{l}\text { 4. Pati } \\
\text { beras } \\
\text { ketan }\end{array}$ & $\begin{array}{l}\text { Kitosan } \\
\text { (derajat } \\
\text { deasetilasi } \\
85 \% \text { ) }\end{array}$ & $(1: 2)$ & $\begin{array}{c}\text { Matri } \\
\text { ks }\end{array}$ & Film & $\begin{array}{l}\text { Lidocaine } \\
\text { Hydrochlo } \\
\text { ride } \\
\text { (LDHC) }\end{array}$ & $\begin{array}{l}\text { Untuk menggabungkan obat } \\
\text { kedalam matriks pati-kitosan } \\
\text { untuk membentuk perangkat } \\
\text { monolitik yang dapat } \\
\text { memperluas penggunaan } \\
\text { komposit biopolimer }\end{array}$ & $\begin{array}{l}{[1} \\
4]\end{array}$ \\
\hline 5. Pati & $\begin{array}{l}\text { Kitosan } \\
\text { (derajat } \\
\text { deasetilasi } \\
\geq 90,0 \% \text { ) }\end{array}$ & $(1: 1)$ & $\begin{array}{l}\text { Polim } \\
\text { er }\end{array}$ & Film & $\begin{array}{l}\text { Glutaralde } \\
\text { hid }\end{array}$ & $\begin{array}{l}\text { Untuk menyiapkan film kitosan- } \\
\text { pati yang berikatan silang dan } \\
\text { tidak dimodifikasi serta } \\
\text { menyelidiki sifat relatifnya }\end{array}$ & $\begin{array}{l}\text { [2 } \\
9]\end{array}$ \\
\hline $\begin{array}{l}\text { 6. } \text { Pati } \\
\text { kacang }\end{array}$ & Kitosan & $(4: 1)$ & $\begin{array}{c}\text { Polim } \\
\text { er }\end{array}$ & Film & $\begin{array}{l}\text { Thyme } \\
\text { extract } \\
\text { polypheno } \\
\text { Is (TE) }\end{array}$ & $\begin{array}{l}\text { Untuk mengevaluasi kinetika } \\
\text { pelepasan polifenol ekstrak } \\
\text { thyme dari film pati kacang- } \\
\text { kitosan dalam pelarut dengan } \\
\text { polaritas yang berbeda, serta } \\
\text { melihat pengaruh penambahan } \\
\text { asam tanat ke dalam matriks } \\
\text { polimer }\end{array}$ & $\begin{array}{l}{[3} \\
1]\end{array}$ \\
\hline $\begin{array}{l}\text { 7. Pati } \\
\text { kentan } \\
\text { g,pati } \\
\text { jagung, } \\
\text { pati } \\
\text { beras } \\
\text { ketan }\end{array}$ & $\begin{array}{l}\text { Kitosan } \\
\text { (derajat } \\
\text { deasetilasi } \\
\geq 95 \% \text { ) }\end{array}$ & $(1: 1)$ & $\begin{array}{l}\text { Polim } \\
\text { er } \\
\text { pemb } \\
\text { entuk } \\
\text { film }\end{array}$ & Film & - & $\begin{array}{l}\text { Untuk menganalisis pengaruh } \\
\text { kandungan amilosa dalam pati } \\
\text { dan menggunakannya sebagai } \\
\text { film komposit kitosan serta } \\
\text { menilai potensinya sebagai } \\
\text { pembalut luka }\end{array}$ & [3] \\
\hline $\begin{array}{l}\text { 8. } \\
\text { Pati } \\
\text { jagung }\end{array}$ & $\begin{array}{l}\text { Kitosan } \\
\text { (derajat } \\
\text { deasetilasi } \\
90 \% \text { ) }\end{array}$ & $(1: 1)$ & $\begin{array}{l}\text { Polim } \\
\text { er } \\
\text { pemb } \\
\text { awa } \\
\text { obat }\end{array}$ & Film & $\begin{array}{l}\text { Hydroxyur } \\
\text { ea }\end{array}$ & $\begin{array}{l}\text { Untuk membuat campuran pati } \\
\text { jagung-kitosan dengan obat } \\
\text { hidroksiurea dan diamati } \\
\text { karakteristik fisikokimia dan } \\
\text { morfologinya, serta } \\
\text { mengevaluasi keefektifan pada } \\
\text { garis sel kanker } \\
\text { Rhabdomyosarcoma (RD) } \\
\end{array}$ & [7] \\
\hline
\end{tabular}


9. Pati Kitosan
(1:3) Polim Nan Bis-
Untuk mensintesis polimer
er opar desmetho nanokomposit kitosan dan pati
pemb tikel $x y$
yang mengandung BDMCA
awa
Curcurmin dengan teknik gelas ionik dan
obat Analogue untuk menentukan efisiensi (BDMCA) pemuatan obatnya

[8]

\begin{tabular}{lll}
\hline 1 & Pati & Kitosan \\
0. & (derajat \\
& & deasetilasi \\
& & $85,5 \%)$
\end{tabular}

$\begin{array}{ccll}\text { (1:1) } & \text { Polim } & \text { Nan } & \text { Ciprofloxa } \\ \text { er } & \text { opar cin } & \\ \text { pemb } & \text { tikel } & \text { Hydrochlo } & \\ \text { awa } & & \text { ride (CIP) } \\ \text { obat } & & \end{array}$

Untuk menyelidiki pengingkatan [1

CIP dengan memasukannya ke 3]

dalam nanokomposit dan

mengontrol pelepasan

antibiotik untuk meningkatkan

bioavailabilitasnya

1 Pati Kitosan

1.

\begin{tabular}{|c|c|c|c|}
\hline $\begin{array}{l}(1: 1) \\
\end{array}$ & $\begin{array}{cc}\text { Polim } & \text { Nan } \\
\text { er } & \text { opa } \\
\text { pemb } & \text { tikel } \\
\text { awa } & \\
\text { obat } & \end{array}$ & Isoniazid & $\begin{array}{l}\text { Untuk mengamati nanopartikel } \\
\text { yang dilapisi dengan kompleks } \\
\text { polielektrolit dari karboksimetil } \\
\text { pati-kitosan dengan pelepasan } \\
\text { terkontrol }\end{array}$ \\
\hline
\end{tabular}

\begin{tabular}{|c|c|c|c|c|c|c|c|c|}
\hline 2. & $\begin{array}{l}\text { Pati } \\
\text { denga } \\
\mathrm{n} \\
\text { amilos } \\
\text { a } \\
\text { tinggi }\end{array}$ & $\begin{array}{l}\text { Kitosan } \\
\text { (derajat } \\
\text { deasetilasil } \\
\text { anjutan), } \\
\text { kitosan } \\
\text { (derajat } \\
\text { deasetilasi } \\
\text { 85\%) }\end{array}$ & $(1: 1)$ & $\begin{array}{c}\text { Matri } \\
\text { ks }\end{array}$ & $\begin{array}{l}\text { Tabl } \\
\text { et }\end{array}$ & $\begin{array}{l}\text { Acetamino } \\
\text { phen }\end{array}$ & $\begin{array}{l}\text { Untuk melihat bagimana } \\
\text { kitosan dan kompleks } \\
\text { polielektrolitnya dengan } \\
\text { karboksimetil pati yang } \\
\text { digunakan sebagai matriks } \\
\text { monolitik }\end{array}$ & $\begin{array}{l}{[3} \\
3]\end{array}$ \\
\hline 3. & $\begin{array}{l}\text { Pati } \\
\text { denga } \\
\mathrm{n} \\
\text { amilos } \\
\text { a } \\
\text { tinggi }\end{array}$ & $\begin{array}{l}\text { Kitosan } \\
\text { (derajat } \\
\text { deasetilasi } \\
92 \% \text { ) }\end{array}$ & $(1: 1)$ & $\begin{array}{l}\text { Matri } \\
\text { ks }\end{array}$ & $\begin{array}{l}\text { Tabl } \\
\text { et }\end{array}$ & $\begin{array}{l}\text { Diamin } \\
\text { Oksidase } \\
\text { (DAO) }\end{array}$ & $\begin{array}{l}\text { Untuk menyelidiki potensi } \\
\text { matriks karboksimetil pati- } \\
\text { kitosan dalam melindungi } \\
\text { enzim PSDAO atau katalase } \\
\text { terhadap kondisi lambung yang } \\
\text { disimulasikan dan untuk } \\
\text { menunda pengiriman dalam } \\
\text { media usus }\end{array}$ & $\begin{array}{l}{[3} \\
5]\end{array}$ \\
\hline
\end{tabular}

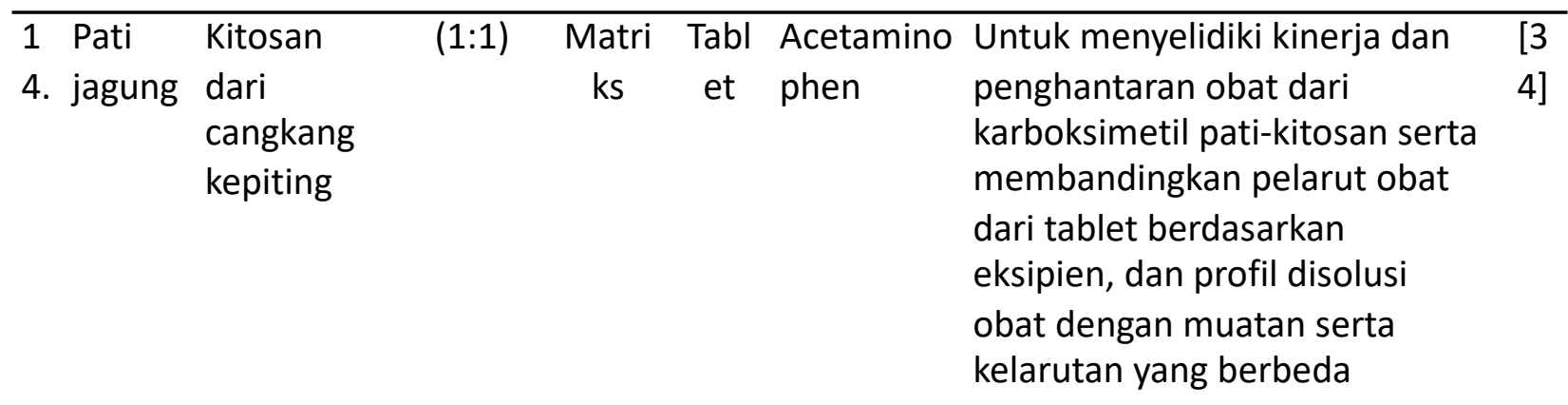




\begin{tabular}{|c|c|c|c|c|c|c|c|}
\hline $\begin{array}{ll}1 & \text { Pati } \\
\text { 5. } & \text { jagung }\end{array}$ & Kitosan & $(1: 1)$ & $\begin{array}{c}\text { Matri } \\
\text { ks }\end{array}$ & $\begin{array}{c}\text { Tabl } \\
\text { et }\end{array}$ & $\begin{array}{l}\text { ovalbulmi } \\
\mathrm{n}\end{array}$ & $\begin{array}{l}\text { Untuk menguji kemampuan } \\
\text { tablet dengan berbagai ekspien } \\
\text { yang berbeda dan digunakan } \\
\text { untuk melindungi ovalbumin } \\
\text { terhadap pencernaan oleh } \\
\text { pepsin di media lambung, serta } \\
\text { membandingkan kinetika } \\
\text { pelepasan ovalbumin dari tablet } \\
\text { dengan berbagai eksipien } \\
\text { dalam kondisi yang di } \\
\text { simulasikan pada transit gasto- } \\
\text { intestinal }\end{array}$ & $\begin{array}{l}{[3} \\
6]\end{array}$ \\
\hline $\begin{array}{ll}1 & \text { Pati } \\
6 & \\
. & \end{array}$ & $\begin{array}{l}\text { Kitosan } \\
\text { (derajat } \\
\text { deasetilas } \\
\text { i 90\%) }\end{array}$ & $(3: 2)$ & $\begin{array}{l}\text { Poli } \\
\text { mer }\end{array}$ & Gel & $\begin{array}{l}\text { Zinc } \\
\text { oxyde } \\
(\mathrm{ZnO})\end{array}$ & $\begin{array}{l}\text { Untuk melihat apakah } \\
\text { membran yang dikembangkan } \\
\text { berdasarkan hidrogel poli vinil } \\
\text { alkohol, pati, dan kitosan } \\
\text { dengan nano seng oksida } \\
\text { dapat digunakan sebagai gel } \\
\text { dalam penyembuhan luka }\end{array}$ & $\begin{array}{l}\text { [3 } \\
7]\end{array}$ \\
\hline
\end{tabular}

\begin{tabular}{|c|c|c|c|c|c|c|c|c|}
\hline $\begin{array}{l}1 \\
7\end{array}$ & $\begin{array}{l}\text { Pati } \\
\text { Kenta } \\
\text { ng }\end{array}$ & $\begin{array}{l}\text { Kitosan } \\
\text { (derajat } \\
\text { deasetilas } \\
\text { i } 85 \% \text { ) }\end{array}$ & $(1: 1)$ & $\begin{array}{c}\text { Poli } \\
\text { mer } \\
\text { pem } \\
\text { bent } \\
\text { uk } \\
\text { gel }\end{array}$ & Gel & - & $\begin{array}{l}\text { Untuk melihat karakteristik } \\
\text { dari gel yang mengandung } \\
\text { partikel mikro/nano pati } \\
\text { dengan kitosan }\end{array}$ & $\begin{array}{l}{[3} \\
8]\end{array}$ \\
\hline $\begin{array}{l}1 \\
8\end{array}$ & $\begin{array}{l}\text { Pati } \\
\text { Jagun } \\
\mathrm{g}\end{array}$ & $\begin{array}{l}\text { Kitosan } \\
\text { (derajat } \\
\text { deasetilas } \\
\text { i } 75 \%- \\
85 \% \text { ) }\end{array}$ & $(1: 1)$ & $\begin{array}{c}\text { Poli } \\
\text { mer } \\
\text { pem } \\
\text { bent } \\
\text { uk } \\
\text { gel }\end{array}$ & $\mathrm{Gel}$ & $\begin{array}{l}\text { Citric } \\
\text { Acid }\end{array}$ & $\begin{array}{l}\text { Untuk melihat pengaruh ikatan } \\
\text { silang dari rasio biopolimer } \\
\text { yang berbeda pada sifat dan } \\
\text { fungsional hidrogel }\end{array}$ & $\begin{array}{l}\text { [3 } \\
9]\end{array}$ \\
\hline
\end{tabular}

Selain itu, kekuatan tarik dan perpanjangan elongasi umumnya dilakukan untuk menggambarkan sifat mekanik film yang dapat mewakili fleksibilitas film dan terkait dengan struktur fisikokimia film ${ }^{25}$. Hasil penelitian menyebutkan kekuatan tarik pada film kitosan-pati memiliki nilai tarik 10,51-15,15 MPa dalam keadaan kering dan 3,765,51 MPa dalam keadaan basah; nilai tersebut menunjukkan hasil yang dapat diterima dan konsisten. Film menjadi lebih fleksibel dalam kelembapan tinggi yang mungkin terjadi karena efek plastisisasi penyerapan kelembapan ${ }^{3}$. Kekuatan tarik film dapat meningkat akibat jumlah kitosan yang digabungkan ${ }^{29,14,25}$. Jika semakin tinggi kandungan kitosan, maka semakin tinggi jumlah gugus amino yang siap membentuk ikatan hidrogen sehingga dapat membuat jaringan polimer lebih kompak dan kuat ${ }^{14}$.

Dalam studi pembengkakan, dinyatakan bahwa perilaku pembengkakan dari setiap jaringan polimer tergantung pada sifat polimer, kompatibilitas pelarut polimer, dan tingkat ikatan silang $22,29,7$. 
Pembengkakan terjadi karena relaksasi dan interpenetrasi rantai polimer ketika kontak dengan media berair; kapasitas pembengkakan menunjukkan kemampuan matriks polimer dalam menyerap dan menahan cairan ${ }^{14}$. Persentasi pembengkakan meningkat seiring dengan meningkatnya persentasi pemuatan obat. Dalam penelitian lainnya, dinyatakan bahwa film menyerap air dengan cepat dalam waktu 30 menit pertama. Film komposit menunjukkan pembengkakan yang cepat karena sifat pati lebih hidrofilik dari pada kitosan ${ }^{3}$.

Dalam suatu studi, telah dilakukan uji koagulasi untuk melihat efektifitas dari film komposit pati-kitosan sebagai pembalut luka. Dari hasil yang didapatkan komposit patikitosan efektif dalam mempercepat pengumpulan trombosit, mendorong koagulasi dari kontak antara darah dan benda asing. Kitosan dapat menarik sel darah merah yang membawa muatan negatif dan menyerap fibrinogen dan protein plasma serta meningkatkan agregasi trombosit, sedangkan pati dapat meningkatkan pembekuan darah. Dalam hal ini, peneliti berasumsi bahwa tingkat pembengkakan film kompsoit mempengaruhi tingkat pembekuan darah ${ }^{3}$.

Studi tentang mekanisme pelepasan obat juga dilakukan untuk mengungkapkan bahwa pelepasan obat dari film sensitif-pH dan medianya serta tergantung pada sifat matriks polimernya ${ }^{22,14,7,31}$. Laju pelepasan obat dari film dalam media $\mathrm{pH}$ dapat diurutkan dengan nilai $\mathrm{pH} 3.5>10.5>5.5>8.5>7.4^{30}$. Dalam media asam, diamati bahwa laju pelepasan obat meningkat secara proporsional seiring dengan meningkatnya waktu pelepasan; penyebab peningkatan pelepasan obat dengan peningkatan waktu dapat dikaitkan dengan hidrasi pati dalam media asam dan adanya protonasi gugus amino kitosan yang memberikan pembengkakan tertinggi pada campuran pati-kitosan dibandingkan dengan media netral 7,40 .

Untuk mendukung fungsi dan menguji toksisitas pada film, dilakukan pengujian antikanker secara in vitro menggunakan garis sel RD. Hasil pengamatan memperlihatkan bahwa campuran obat dengan pati-kitosan dalam persentasi yang berbeda memiliki efek toksisitas dan efektif membunuh sel kanker dalam konsentrasi tertentu. Selanjutnya, komposit film ini menunjukkan hasil farmakodinamik obat yang dienkapsulasi dan mampu menunjukkan potensi untuk penggunaan yang lebih luas ${ }^{30}$.

\section{Nanopartikel}

Telah ada beberapa peneliti yang mengembangkan komposit pati-kitosan dalam bentuk nanokomposit ${ }^{8,13}$. Pati dan kitosan yang dibuat dalam bentuk nanopartikel (polimer alam) bertujuan agar obat lebih efisien dalam sistem penghantarannya didalam tubuh dengan keamanan yang tinggi serta membantu dalam meningkatkan biokompatibilitas ${ }^{13}$ dan bentuk nanopartikel ini menawarkan hasil yang terbaik dengan menunjukkan pengurangan toksisitas yang membatasi interaksinya dengan sel ${ }^{8}$. Dalam suatu studi, ditemukan bahwa sifat mukoadhesif pati dapat ditingkatkan hasilnya jika dikombinasikan dengan kitosan, dan penggabungan pati-kitosan menunjukkan sifat mukoadhesif yang sangat baik. 
Selanjutnya dilakukan pengujian kandungan obat dan efisiensi enkapsulasi obat, hasil menunjukkan bahwa presentasi kandungan obat dan efisiensi enkapsulasi obat meningkat dengan meningkatnya konsentrasi polimer; peningkatan lebih dominan dengan meningkatnya konsentrasi kitosan ${ }^{8}$. Untuk studi in vitro, pelepasan obat pada film dengan konsentrasi kitosan lebih besar dari pati menunjukkan pelepasan yang sangat lambat dan mampu digunakan untuk mempertahankan obat dalam jangka waktu yang lama, sehingga memfasilitasi pelepasan obat yang terkontrol dan berkelanjutan ${ }^{8}$. Dalam penelitian lainnya, ditemukan hasil laju pelepasan tertinggi (yaitu $86 \%$ ) dicapai dalam waktu $20 \mathrm{jam}$, dan ini diakibatkan dari kerusakan struktur kitosan pada $\mathrm{pH}$ yang lebih rendah yang mengarah pada pelepasan obat dalam media ${ }^{13,32}$. Hal itu sejalan dengan hasil kinetika pelepasan obat, yaitu pada plot Krosmeyer-Peppas dan HixsonCrowell dengan nilai linearitas yang terbaik; hasilnya menunjukkan bahwa indikator pelepasan obat berkelanjutan dilakukan oleh difusi ${ }^{41}$ dan erosi polimer. Kemudian, uji antikanker dilakukan sebagai uji lanjutan untuk menyelidiki kemampuan partikel nanokomposit pati-kitosan dalam melepaskan obat ke sel kanker melalui penargetan tumor pasif. Hasil yang didapat yaitu obat (BDMCA) dengan komposit pati-kitosan sebagai agen antikanker dapat menginduksi kematian sel melalui sitotoksisitasnya ${ }^{8}$.

Selain itu, dilakukan pengujian hambat minimum terhadap bakteri gram negatif. Pengujian pati tunggal tidak menunjukkan perubahan warna untuk semua strain bakteri sehingga disimpulkan bahwa tidak adanya aktivitas penghambatan. Berbeda halnya dengan komposit pati-kitosan yang menunjukkan peningkatan aktivitas antibakteri akibat peran ganda pati sebagai agen penstabil dan pembawa untuk kitosan. Hal tersebut juga dapat disebabkan oleh sifat polikationik pati-kitosan dengan luas permukaan lebih besar dan kepadatan muatan permukaan positif yang memungkinkan peningkatan reaksi dengan membran sel bakteri bermuatan negatif dan menyebabkan perubahan permeabilitas sel. Sifat polikationik pada kitosan dengan mengubahnya menjadi ukuran nano dapat menyebabkan kematian bakteri ${ }^{13}$.

\section{Tablet}

Pada umumnya, tablet menggunakan eksipien tunggal. Namun semakin berkembangnya ilmu, telah ada penggabungan dua eksipien menjadi satu material yaitu komposit pati-kitosan. Salah satu pengujian tablet yaitu pengujian terhadap sifat fisika. Dari beberapa hasil penelitian, diperoleh kesimpulan bahwa sifat fisika tablet dapat mempengaruhi perilaku pelepasan obat dalam media gatro-intestinal buatan; hal ini berkaitan dengan hasil uji waktu hancur dan kekerasan tablet. Tablet dengan patikitosan memiliki kekerasan yang lebih tinggi dari pada tablet tanpa pati-kitosan; hal ini menunjukkan bahwa penambahan pati-kitosan berperan mendukung stabilitas fisika tablet setelah dikompresi. Pati memberikan nilai kekerasan tablet sebesar $128 \mathrm{~N}$, sedangkan campuran pati-kitosan memberikan nilai kekerasan tablet sebesar 176-179 $\mathrm{N}^{35,36}$.

Dalam suatu penelitian, komposit pati-kitosan mampu mempertahankan bentuk tablet menjadi lebih baik dan menunjukkan pembengkakan tingkat sedang setelah terjadinya pembengkakan lapisan hidrogel. Kemudian, 
dilakukan pengujian fisik dan $\mathrm{pH}$ tablet untuk mengamati sejauh mana komposit dapat melindungi obat terhadap cairan lambung buatan. Hasil visual penampang tablet menunjukkan terdapat lapisan gel penghalang sehingga inti tablet kering. Fenomena tersebut mendukung asumsi bahwa asosiasi elektrostatik komposit pati-kitosan dapat berpotensi sebagai pembawa yang melindungi enzim terapeutik atau probiotik untuk penghantaran kolon ${ }^{33}$. Pada pengamatan pengujian $\mathrm{pH}$, permukaan seluruh tablet berwarna biru selama 60 menit dengan inkubasi dalam asam (cairan lambung buatan). Hal ini menunjukkan matriks pati karbosimetil-kitosan mampu membentuk penghalang gel luar sehingga memberikan perlindungan terhadap keasaman lambung ${ }^{35}$.

Kemudian dalam pengujian lainnya, campuran pati-kitosan menunjukkan hasil difusi cairan tercepat dan pembengkakan tetinggi ${ }^{34}$. Pati karboksimetil dapat melindungi agen bioaktif pada cairan lambung dan memberikan pelepasan obat yang terkontrol dalam media usus. Pada pH 1,2 (media lambung), pati karboksimetil yang berada pada bagian luar tablet akan terprotonasi dan membuat matriks yang lebih kompak ${ }^{32}$; pada $\mathrm{pH}$ yang lebih tinggi (media usus), gugus karboksil terdeprotonasi dan terionisasi sehingga mendorong hidrasi dan pembengkakan tablet yang akhirnya terjadi pelarutan tablet $33,34,35$. Hal ini terjadi karena penyerapan cairan oleh tablet tergantung pada $\mathrm{pH}$ media yang digunakannya. Pada media lambung, serapan dari komposit pati-kitosan memberikan hasil yang baik dibandingkan pada media usus. Tablet dengan komposisi pati dapat memberikan tablet yang relatif kompak pada media lambung, sedangkan tablet dengan komposisi kitosan dapat membentuk lapisan hidrogel yang membatasi penetrasi cairan lambung ke dalam tablet. Namun, tablet dengan gabungan pati-kitosan mampu mengambil lebih banyak cairan sehingga difusi pada cairan lambung lebih cepat ke dalam tablet ${ }^{36}$.

Uji pelepasan obat dengan disolusi juga dilakukan dengan menggunakan media usus dan lambung buatan. Daya tarik elektrostatik yang terbentuk antara anionik (karboksimetil) dan kationik (amino) kitosan dapat membantu mempertahankan bentuk tablet dan mengontrol pelepasan obat. Tablet dengan kandungan pati hancur sepenuhnya dalam waktu kurang dari 2 jam di cairan usus, sedangkan dengan adanya kitosan dalam tablet komposit pati-kitosan dapat mempertahankan bentuknya hingga 7,5 jam. Hal ini terjadi ketika kitosan berada dalam lingkungan asam, penghalang gel yang membatasi laju terbentuk sehingga menghasilkan pelepasan obat yang lebih lambat ${ }^{33}$. Hal tersebut di dukung dalam penelitian lainnya bahwa semakin tinggi berat molekul kitosan, semakin rendah laju pelepasannya, dan kelarutan suatu obat memiliki pengaruh besar pada laju pelepasannya. Penambahan kitosan dalam jumlah cukup dengan berat molekul yang sesuai pada formulasi dan penggabungannya dengan pati dapat memperpanjang pelepasan obat, contohnya asetaminofen ${ }^{34}$. Keberadaan kitosan dalam tablet secara proporsional dapat meningkatkan waktu pelepasan, hal ini kemungkinan terjadi karena interaksi elektrostatik yang menguntungkan antara dua polimer yang berbeda muatan dan kemampuan tablet komposit pati-kitosan dalam mempertahankan integritasnya. Hasil menunjukkan campuran pati-kitosan dengan perbandingan (1:1) menghasilkan waktu pelepasan terlama baik di media lambung maupun usus ${ }^{33,36}$. 


\section{Gel dan Hidrogel}

Pati sebagai biopolimer alam telah terbukti dapat menjadi bahan prekursor yang baik untuk membuat hidrogel ${ }^{37}$. Selain itu, kitosan dapat berperan sebagai plasticizer untuk hidrogel pati-kitosan karena rantai biopolimer kationik diposisikan dalam celah jaringan koloid bersama dengan rantai amilosa dan amilopektin ${ }^{42}$. Pati yang disintesis dengan gelatinisasi memiliki bentuk yang bulat-padat dan permukaan yang kompak, halus dan tidak berpori38; studi lain menyatakan native pati dan kitosan, masing-masing, menunjukkan bentuk granul oval dengan permukaan halus ${ }^{39}$. Hasil pengujian SEM pada hidrogel komposit pati-kitosan-PVA memberikan informasi bahwa granula pati larut sempurna dan diperoleh fase kontinu ${ }^{37}$. Penggabungan partikel pati dalam hidrogel ini memiliki pengaruh yang cukup besar terhadap morfologi matriks kitosan dan membuat struktur hidrogel kitosan lebih koheren dan terintegrasi. Pada dasarnya, kombinasi ini menyebabkan matriks kitosan lebih terikat silang melalui partikel pati yang bertindak sebagai simpul pengikat silang dan mencegah pada peningkatan sifat mekanik hidrogel ${ }^{38}$.

Pembengkakan hidrogel terjadi ketika ditempatkan dalam air dan terdapat penahanan sebagian besar air dalam struktur spasialnya tanpa larut ${ }^{39}$. Kapasitas penahanan air atau pembengkakan hidrogel memiliki peran penting dalam aktivitas antibakteri dan pemulihan luka. Membran hidrogel dapat menyerap eksudat luka dalam jumlah kecil hingga sedang melalui pembengkakan dan membantu pemulihan luka dengan cepat. Faktor tejadinya pembengkakan hidrogel tergantung pada sifat jaringan polimer seperti keberadaan gugus hidrofilik atau hidrofobik ${ }^{12}$, kerapatan ikatan silang, elastisitas jaringan polimer, $\mathrm{pH}$, dan suhu pada lingkungan pembengkakan ${ }^{37,43}$. Faktor lainnya adalah penggabungan partikel kecil dalam hidrogel kitosan menghasilkan koefisien pembengkakan partikel yang lebih tinggi akibat luas permukaan spesifiknya lebih besar. Hal tersebut mengakibatkan difusi melalui permukaan menjadi lebih tinggi ${ }^{38}$. Dalam penelitian lainnya, dikatakan struktur hidrogel kitosan yang lebih amorf dapat mengakibatkan peningkatan volume bebas dan memudahkan difusi molekul air ${ }^{39}$. Laporan suatu penelitian menyatakan kapasitas pembengkakan gabungan pati-kitosan bernilai tinggi. Peningkatan kandungan kitosan dalam hidrogel dapat meningkatkan kapasitas pembengkakan karena keberadaan lebih banyak gugus hidrofilik dalam jaringan. Studi ini memperlihatkan semua hidrogel memiliki kapasitas menyerap air yang lebih tinggi dilingkungan asam daripada dilingkungan basa akibat keberadaan gugus amino. Gugus amino pada kitosan terprotonasi dalam lingkungan asam dan menyebabkan tolakan elektrostatik serta pemisahan ikatan hidrogen di antara polimer dan pelepasan rantai makromolekul yang pada akhirnya mengarah pada peningkatan rasio pembengkakan. Sedangkan dalam lingkungan netral atau basa, gugus amino kitosan terdeprotonasi dan tolakan elektrostatik menurun menyebabkan penurunan karakteristik pembengkakan ${ }^{37}$.

Efek $\mathrm{pH}$ terhadap pembengkakan hidrogel telah diamati dalam suasana asam, basa, dan netral. Hasilnya memperlihatkan bahwa semua hidrogel menunjukkan penyerapan air yang tinggi pada $\mathrm{pH} \mathrm{7,5}$ akibat keberadaan gugus hidroksil pati dan gugus amino kitosan. 
Pada $\mathrm{pH}$ tersebut, molekul air mengalami ikatan hidrogen sehingga membentuk lebih banyak ruang sebagai tempat berpenetasinya molekul lain dan menghasilkan pembengkakan lebih tinggi. Diungkapkan juga bahwa pengikatan gugus glikosan dengan hidrogel secara bertahap menyebabkan peningkatan kerapatan muatan di dalam hidrogel sehingga meningkatkan hidrofilisitas di dalam hidrogel yang akhirnya mengarah pada peningkatan kapasitas pembengkakan ${ }^{39}$.

Kandungan air hidrogel dapat menentukan permeasi bahan dalam gel. Hidrogel sebagai matriks dalam rekayasa jaringan harus terhidrasi. Keberadaan molekul air akan berinteraksi dengan gugus hidrofilik-hidrofobik polimer membentuk primary bound water dan secondary bound water, kelebihan molekul air yang tidak terikat dan mengisi ruang kosong disebut sebagai free water. Fenomena tersebut menjelaskan proses pembengkakan yang terjadi pada hidrogel. Penentuan kandungan air hidrogel sangat penting dilakukan karena terkait dengan aktivitas biomedis dan farmasetikal akibat interaksi molekul air dengan polimer atau jaringan. Di sisi lain, pati tipe soluble dapat meningkatkan kelarutan membentuk gel dalam air; struktur kaku dan keberadaan rantai cabang pada pati dapat mendukung lebih banyak ikatan molekuler dengan matriks PNIPA $^{43}$. Pembengkakan yang terjadi pada hidrogel pati-kitosan berpotensi sebagai pembalut luka yang dapat menyerap eksudat dan mencegah infeksi. Hal in terjadi karena daya serap air yang tinggi dari kitosan sehingga mencegah pengumpulan cairan pada luka dan mengurangi resiko infeksi ${ }^{37}$.

Telah dilakukan pengamatan efek surfaktan dalam sediaan gel. Hasil menunjukkan bahwa ukuran partikel pati berkurang dengan meningkatnya penambahan surfaktan. Efek reduksi surfaktan terhadap ukuran partikel dijelaskan oleh pengaruh tween 80 dan span 80 sebagai emulsifier pada pembentukan misel berukuran lebih kecil. Selain itu, peningkatan laju pengadukan dapat meningkatkan energi dalam pemecahan tetesan emulsi sehingga membentuk misel yang lebih halus dan akhirnya membentuk partikel ${ }^{38}$.

Pengujian transmisi uap air juga dilakukan dan dinyatakan bahwa peningkatan jumlah kitosan dapat meningkatkan laju transmisi uap air. Penggunaan hidrogel pada luka dengan sifat tersebut akan menyebabkan permukaan luka menjadi kering ${ }^{37}$. Pada penggunaan tunggal, hidrogel pati memiliki fraksi gel terendah sekitar $34 \%$ dan kitosan termodifikasi asam sitrat memiliki fraksi gel tertinggi sekitar $91 \%$. Perbedaan yang signifikan dipengaruhi oleh sifat kitosan dan pati itu sendiri. Kitosan tidak larut dalam air deionisasi pada $\mathrm{pH}$ netral, namun pati dapat larut sebagian karena hidrofilisitasnya. Selain itu, pengurangan rantai pati dapat terjadi pada $\mathrm{pH}$ rendah yang mengakibatkan penurunan kandungan ge ${ }^{39}$.

Pengamatan sifat mekanik hidrogel memperlihatkan penurunan kuat tarik ketika jumlah kitosan ditingkatkan. Peningkatan ini membuat elongasi hidrogel menurun akibat peningkatan pori-pori pada jaringan dan menurunkan ikatan silang ${ }^{37}$. Ukuran dan kandungan partikel dapat mempengaruhi waktu gelasi dan modulus pada hidrogel; hal ini dapat dinyatakan dengan meningkatnya kandungan pati dalam larutan hidrogel kitosan dapat mempersingkat waktu gelasi karena partikel pati bertindak sebagai simpul pengikat silang dan menfasilitasi gelasi larutan kitosan ${ }^{38}$. 
Waktu gelasi hidrogel menurun dari $25 \pm 0,1$ menit menjadi $7 \pm 0,1$ menit pada $30 \mathrm{mg}$ nanopartikel pati yang berukuran rata-rata $128 \pm 0,02 \mathrm{~nm}$ dalam hidrogel. Hal tersebut menunjukkan bahwa pada fraksi pengisi yang sama, partikel berukuran kecil menyebabkan waktu gelasi lebih pendek karena bertambahnya jumlah simpul pengikat silang dalam menghasilkan ikatan silang lebih cepat pada hidrogel kitosan. Kandungan partikel pati dapat berpengaruh terhadap modulus elastisitas hidrogel kitosan; semakin halus ukuran partikel semakin tinggi peningkatan modulus dan semakin banyak jumlah titik ikatan silang dalam hidrogel mengakibatkan semakin tinggi modulus elastisitas campuran ini. Pengaruh positif partikel pati yang dapat memuat hingga $20 \mathrm{mg}$ pada modulus elastisitas hidrogel dapat dikaitkan dengan fakta bahwa partikel ikatan silang ini bertindak sebagai penguat dalam matriks hidrogel lunak ${ }^{38}$.

Uji sitotoksisitas pada gel dilakukan dengan uji MMT untuk memeriksa biokompatibilitas bahan dan sitotoksisitas hidrogel yang dianalisis menggunakan sel fibroblas dermal manusia. Hasil uji menunjukkan bahwa hidrogel yang disintesis tidak berpengaruh pada pertumbuhan sel-sel ini karena viabilitas sel masih diatas $87 \%$ yang berarti hidrogel pati-kitosan ini memiliki toksisitas yang sangat rendah terhadap sel fibroblas L92937. Studi antibakteri in vitro juga dilakukan pada campuran pati-kitosan. Hasilnya menunjukkan bahwa terdapat lingkaran zona hambat disekitar sampel dan aktivitas antibakteri yang terbatas. Fenomena ini terjadi karena muatan positif pada kitosan dihasilkan oleh pasangan elektron bebas nitrogen dalam $\mathrm{NH}_{2}$ dan memungkinkan kitosan berikatan dengan semua permukaan biologis seperti dinding sel bakteri yang memiliki muatan negatif dan menyebabkan kebocoran dinding sel yang akhirnya menyebabkan kematian bakteri ${ }^{37}$.

\section{Kesimpulan}

Penggunaan gabungan pati dan kitosan telah dinyatakan dalam berbagai penelitian bahwa komposit ini memiliki kemampuan dan fungsi yang optimal dalam mencapai sifat fisika kimia yang diharapkan pada sistem penghantaran obat. Penggabungan keduanya membentuk material baru dari material tunggal dengan sifat yang melengkapi satu sama lain. Pada penerapannya, komposit dalam sediaan film menunjukkan kompatibilitas yang baik, meningkatkan termostabilitas film, meningkatkan biodegradasi, mampu menahan kelembaban air sehingga dapat digunakan sebagai pembalut luka karena sifat pembengkakannya. Selain itu, penggunaannya sebagai nanopartikel mampu memberikan efisiensi dalam sistem penghantaran dengan keamanan yang tinggi dan meningkatkan biokompatibilitasnya. Penggunaannya dalam sediaan tablet mampu memberikan profil laju pelepasan terkontrol dalam media lambung. Terakhir, penggunaannya dalam sediaan gel juga berpotensi sebagai pembalut luka karena sifat pembengkakan dan daya serap air yang tinggi sehingga mencegah pengumpulan cairan pada luka dan menurunkan resiko infeksi.

\section{Daftar Pustaka}

1. Putri RE, Husni P. Potensi Pati Asal Tanaman Waluh (Sechium edule) Sebagai Alternatif Eksipien Farmasi. Farmaka. 2017 Jul 30;15(2):42-52. 
2. Priyanta S, Bagus R, Arisanti S, Istri C. Sifat Fisik Granul Amilum Jagung Yang Dimodifikasi Secara Enzimatis Dengan Lactobacilus Acidophilus Pada Berbagai Waktu Fermentasi. Jurnal Farmasi Udayana. 2012;1(1):279841.

3. Wu WC, Hsiao PY, Huang YC. Effects of amylose content on starch-chitosan composite film and its application as a wound dressing. Journal of Polymer Research. 2019 Jun;26(6):1-3.

4. Kamsiati E, Herawati H, Purwani EY. Potensi pengembangan plastik biodegradable berbasis pati sagu dan ubikayu di Indonesia. Jurnal Penelitian dan Pengembangan Pertanian. 2017 Dec 29;36(2):67-76.

5. Yasar H, Ho DK, De Rossi C, Herrmann J, Gordon S, Loretz B, Lehr CM. Starchchitosan polyplexes: A versatile carrier system for anti-infectives and gene delivery. Polymers. 2018 Mar; 10(3):252.

6. Abukhadra MR, Refay NM, Nadeem A, El-Sherbeeny AM, Ibrahim KE. Insight into the role of integrated carbohydrate polymers (starch, chitosan, and $\beta$ cyclodextrin) with mesoporous silica as carriers for ibuprofen drug; equilibrium and pharmacokinetic properties. International journal of biological macromolecules. 2020 Aug 1;156:537-47.

7. Alwaan IM, Ahmed M, Al-Kelaby KK, Allebban ZS. Starch-chitosan modified blend as long-term controlled drug release for cancer therapy. Pakistan Journal of Biotechnology. 2018 Dec 25;15(4):947-55.

8. Subramanian SB, Francis AP, Devasena T. Chitosan-starch nanocomposite particles as a drug carrier for the delivery of bis-desmethoxy curcumin analog. Carbohydrate polymers. 2014 Dec 19;114:170-8.

9. Sarwar MS, Huang Q, Ghaffar A, Abid MA, Zafar MS, Khurshid Z, Latif M. A smart drug delivery system based on biodegradable chitosan/poly (allylamine hydrochloride) blend films. Pharmaceutics. 2020 Feb;12(2):131.

10. Ahmed S, Ikram S, editors. Chitosan: derivatives, composites and applications. John Wiley \& Sons; 2017 Sep 14.

11. Arifki HH, Zaman NN, Pakpahan WH, Silalahi K, Pertiwi I, Wathoni N. Kitosan sebagai Eksipien dalam Sistem Penghantaran Obat Baru. Farmaka. 2018 Nov 10;16(3).

12. Hamedi H, Moradi S, Hudson SM, Tonelli AE. Chitosan based hydrogels and their applications for drug delivery in wound dressings: A review. Carbohydrate polymers. 2018 Nov 1;199:445-60.

13. Shehabeldine A, Hasanin M. Green synthesis of hydrolyzed starch-chitosan nano-composite as drug delivery system to gram negative bacteria. Environmental Nanotechnology, Monitoring \& Management. 2019 Dec 1;12:100252.

14. Soe MT, Pongjanyakul T, Limpongsa E, Jaipakdee N. Modified glutinous rice starch-chitosan composite films for buccal delivery of hydrophilic drug. Carbohydrate polymers. 2020 Oct 1;245:116556. 
15. Lisdayana N, Larasati DA, Yunira EN. Teknologi Produksi Plastik Biodegradable Berbasis Pati Dan Pemanfaatannya Sebagai Bahan Kemasan.

16. Fajri RI, Tarkono T, Sugiyanto S. Studi Sifat Mekanik Komposit Serat Sansevieria Cylindrica dengan Variasi Fraksi Volume Bermatrik Polyester (Doctoral dissertation, Lampung University).

17. Jordy W, Fadli A, Drastinawati D. Sintesis Magnetite/Hidroksiapatit Composite Menggunakan Metode Presipitasi Dengan Variasi Magnetite Dan Suhu Pemanasan. JOM FTEKNIK. 2019 Jan;6(0):1-6.

18. Suryanto $\mathrm{H}$. Biokomposit Starch-Nanoclay: Sintesis Dan Karakterisasi. Malang: Universitas Negri Malang; 2019. $128 \mathrm{hlm}$.

19. Faridah HD, Susanti T. Polisakarisa Sebagai Material Pengganti Gelatin Pada Halal Drug Delivery System. Journal of Halal Product and Research (JHPR). 2018 Nov.

20. Ramadon D, Mun'im A. Pemanfaatan nanoteknologi dalam sistem penghantaran obat baru untuk produk bahan alam. Jurnal IImu Kefarmasian Indonesia. 2017 Sep 4;14(2):118-27.

21. Winarti L. Sistem penghantaran obat tertarget, macam, jenis-jenis sistem penghantaran, dan aplikasinya. STOMATOGNATIC-Jurnal Kedokteran Gigi. 2015 Dec 15;10(2):75-81.

22. Mohanty DP, Biswal S, Nayak L. Preparation of starch-chitosan nanocomposites for control drug release of curcumin. Int. J. Curr. Eng. Technol. 2015;5:336-43.

23. Vilar G, Tulla-Puche J, Albericio F. Polymers and drug delivery systems. Current drug delivery. 2012 Jul 1;9(4):367-94.

24. Lestari AD, Siswanta D, Martien R, Mudasir M. Synthesis, characterization, and stability evaluation of $\beta$-Carotene encapsulated in starchchitosan/tripolyphosphate matrices. Indonesian Journal of Chemistry. 2020;20(4):929-40.

25. Lian R, Cao J, Jiang X, Rogachev AV. Physicochemical, antibacterial properties and cytocompatibility of starch/chitosan films incorporated with zinc oxide nanoparticles. Materials Today Communications. 2021 Jun 1;27:102265.

26. Zhao Y, Saldaña MD. Hydrolysis of cassava starch, chitosan and their mixtures in pressurized hot water media. The Journal of Supercritical Fluids. 2019 May 1;147:293- 301.

27. Odeniyi MA, Omoteso OA, Adepoju AO, Jaiyeoba KT. Starch nanoparticles in drug delivery: A review. Polim. W Med. 2018 Jan 1;48:41-5.

28. Abdassah M. Nanopartikel dengan gelasi ionik. Farmaka. 2017 May 8;15(1):4552.

29. Li H, Gao X, Wang Y, Zhang X, Tong Z. Comparison of chitosan/starch composite film properties before and after cross-linking. International journal of biological macromolecules. 2013 Jan 1;52:275-9.

30. Huo W, Xie G, Zhang W, Wang W, Shan J, Liu H, Zhou X. Preparation of a novel chitosan-microcapsules/starch blend film and the study of its drug-release mechanism. International journal of biological macromolecules. 2016 Jun 1;87:114-22. 
31. Talón E, Trifkovic KT, Vargas M, Chiralt A, González-Martínez C. Release of polyphenols from starch-chitosan based films containing thyme extract. Carbohydrate polymers. 2017 Nov 1;175:122-30.

32. Saikia C, Hussain A, Ramteke A, Sharma HK, Maji TK. Carboxymethyl starchchitosan-coated iron oxide magnetic nanoparticles for controlled delivery of isoniazid. Journal of microencapsulation. 2015 Jan 2;32(1):29-39.

33. Leonida M, Ispas-Szabo $P$, Mateescu MA. Self-stabilized chitosan and its complexes with carboxymethyl starch as excipients in drug delivery. Bioactive materials. 2018 Sep 1;3(3):334-40.

34. Assaad E, Wang YJ, Zhu XX, Mateescu MA. Polyelectrolyte complex of carboxymethyl starch and chitosan as drug carrier for oral administration. Carbohydrate polymers. 2011 Apr 2;84(4):1399-407.

35. Calinescu C, Mondovi B, Federico R, Ispas-Szabo P, Mateescu MA. Carboxymethyl starch: chitosan monolithic matrices containing diamine oxidase and catalase for intestinal delivery. International Journal of Pharmaceutics. 2012 May 30;428(1-2):48-56.

36. Assaad E, Blemur L, Lessard M, Mateescu MA. Polyelectrolyte complex of carboxymethyl starch and chitosan as protein carrier: oral administration of ovalbumin. Journal of Biomaterials Science, Polymer Edition. 2012 Sep 1;23(13):1713-28.

37. Baghaie S, Khorasani MT, Zarrabi A, Moshtaghian J. Wound healing properties of PVA/starch/chitosan hydrogel membranes with nano Zinc oxide as antibacterial wound dressing material. Journal of Biomaterials Science, Polymer Edition. 2017 Dec 12;28(18):2220-41.

38. Baniani DD, Bagheri R, Solouk A. Preparation and characterization of a composite biomaterial including starch micro/nano particles loaded chitosan gel. Carbohydrate polymers. 2017 Oct 15;174:633-45.

39. Peidayesh H, Ahmadi Z, Khonakdar HA, Abdouss M, Chodák I. Baked hydrogel from corn starch and chitosan blends cross-linked by citric acid: Preparation and properties. Polymers for Advanced Technologies. 2020 Jun;31(6):1256-69.

40. Wang G, Li R, Parseh B, Du G. Prospects and challenges of anticancer agents' delivery via chitosan-based drug carriers to combat breast cancer: A review. Carbohydrate Polymers. 2021 May 13:118192.

41. Bansal V, Sharma PK, Sharma N, Pal OP, Malviya R. Applications of chitosan and chitosan derivatives in drug delivery. Advances in Biological Research. 2011;5(1):28-37.

42. de Souza Soares L, Gomes BT, Miliao GL, da Rocha RA, de Carvalho Teixeira AV, dos Reis Coimbra JS, de Oliveira EB. Mixed starch/chitosan hydrogels: elastic properties as modelled through simulated annealing algorithm and their ability to strongly reduce yellow sunset (INS 110) release. Carbohydrate Polymers. 2021 Mar 1;255:117526. 
43. Vieira JN, Posada JJ, Rezende RA, Sabino MA. Starch and chitosan oligosaccharides as interpenetrating phases in poly ( $\mathrm{N}$-isopropylacrylamide) injectable gels. Materials Science and Engineering: C. 2014 Apr 1;37:20-7.

44. Nining N, Elfiyani R, Wulandari E. Comparison eugenol and oleic acid as a plasticizer on characteristic of dextromethorphan hydrobromide film by solvent casting method. Pharmaceutical Sciences Asia. 2021;48(2):139-146. 